\title{
PENGANTAR STATISTIKA PENDIDIKAN
}

\author{
Nama : Nilda Miftahul Janna \\ NIM : 18210047 \\ Email : nildamiftahuljanna@gmail.com
}

\begin{abstract}
ABSTRAK
Statistika telah banyak berperan dan digunakan dalam kehidupan sehari-hari. Dalam dunia penelitian atau riset, seringkali statistika harus digunakan untuk mempermudah pengumpulan data,bukan semata-mata karena statistika memberikan manfaat yang baik dalam penelitian atau riset tersebut. Statistika banyak diterapkan dalam berbagai disiplin ilmu, baik ilmu-ilmu alam, misalnya astronomi dan biologi maupun ilmu-ilmu sosial (termasuk sosiologi dan psikologi), maupun di bidang bisnis, ekonomi, dan industri. Statistika juga digunakan dalam pemerintahan untuk berbagai macam tujuan misalnya sensus penduduk yang merupakan salah satu prosedur yang paling populer. Dalam urusan politik pun terdapat aplikasi statistika yang begitu popular, yaitu prosedur jajak pendapat atau polling (misalnya dilakukan sebelum pemilihan umum), serta jajak cepat (perhitungan cepat hasil pemilu) atau quick count. Masyarakat pada umumnya masih belum dapat memahami istilah statistik dan statistika. Masyarakat cenderung mengartikan kata statistik dan statistika dalam pengertian yang sama. Padahal keduanya memiliki pengertian yang berbeda. Untuk lebih jelasnya, berikut ini akan diuraikan tentang pengertian statistik, statistika, statistika pendidikan, data, populasi, sampel, penggolongan statistika, macam-macam statistika, serta kegunaan statistika dalam berbagai bidang.
\end{abstract}

Kata Kunci : Statistik, Statistika, Data, Populasi, Sampel

\section{PENDAHULUAN}

\section{A. Latar belakang}

Pada setiap lapangan pekerjaan, baik pemerintahan, pendidikan, pertanian, perdagangan, maupun lapangan pekerjaan lain, setiap pimpinan instansi (manajer) selau berhadapan dengan masalah atau persoalan yang antara lain dinyatakan dengan angka-angka. Dari kumpulan angka tersebutlah manajer tersebut berusaha menarik kesimpulan yang dianggap atau diharapkan cukup beralasan untuk memberikan gambaran atau penjelasan mengenai persoalan itu. Sedangkan untuk memberikan kesimpulan itu, pimpinan (manajer) menyusun dan menyajikan angka-angka tersebut dalam sebuah daftar atau label. 
Hal inilah yang dinamakan statistik, jadi dapat disimpulkan statistik adalah kesimpulan fakta berbentuk angka yang disusun dalam bentuk daftar atau tabel yang menggambarkan suatu persoalan. macam-macam statistik menurut penggolongannya di bedakan dalam beberapa macam seperti dalam bidang cara pengolahannya, ruang lingkup penggunaan atau disiplin ilmu. Pada kesempatan kali ini kita hanya akan membahas macam-macam statistik berdasarkan metode pengolahan data.

B. Rumusan masalah

1. Apa yang dinamakan statistik?

2. Apa saja pembagian statistik berdasarkan metode pengolahannya?

3. Apa fungsi statistik?

4. Bagaimana kegunaan statistik?

5. Dan apa saja ciri-ciri statistik?

C. Tujuan pembahasan

1. Agar kita tahu apa itu statistik

2. Agar kita tahu apa saja jenis atau macam statistik berdasarkan metode pengolahannya

3. Agar kita tahu fungsi statistik

4. Dan mengerti bagaimana kegunaan statistik

5. Serta bisa memahami statistik melalui ciri-cirinya

\section{DEFINISI}

\section{STATISTIK (STATISTIC)}

Istilah untuk menyatakan kumpulan data, bilangan maupun non bilangan yang disusun dalam diagram atau tabel yang melukiskan atau menggambarkan suatu persoalan.

> Istilah untuk menyatakan ukuran sebagai wakil dari kumpulan data mengenai suatu hal. Ukuran ini diambil berdasarkan perhitungan menggunakan kumpulan sebagai data yang diambil dari keseluruhan tentang persoalan tersebut.

$>$ Rekapitulasi dari fakta yang berbentuk angka-angka yang di susun dalam bentuk tabel dan diagram yang mendeskripsikan suatu permasalahan. 


\section{STATISTIKA (STATISTICS)}

$>$ Pengetahuan yang berhubungan dengan cara-cara pengumpulan data, pengolahan atau penganalisisannya dan penarikan kesimpulan berdasarkan kumpulan data dan penganalisisan yang dilakukan.

$>\quad$ Ilmu pengetahuan yang berhubungan dengan data statistik dan fakta yang benar.

> Kajian ilmu pengetahuan tentang teknik pengumpulan data, pengolahan data, analisis data dan sebagainya. Berdasarkan data dan fakta yang benar.

\section{STATISTIK PENDIDIKAN}

adalah ilmu pengetahuan, yang membahas atau mempelajari dan mengembangkan prinsip-prinsip, metode, dan prosedur yang ditempuh atau dipergunakan dalam rangka pengumpulan, penyusunan, penyajian, penganalisisan bahan keterangan yang berwujud angka mengenai hal-hal yang berkaitan dengan pendidikan (khususnya proses belajar mengajar), penarikan kesimpulan, perkiraan serta ramalan secara ilmiah (dalam hal ini secara matematik) atas dasar kumpulan bahan keterangan yang berwujud angka.

\section{DATA}

Data adalah hasil observasi atau pengamatan yang telah dikumpulan. Data dapat berupa hasil pengukuran; misalnya data tinggi dan berat badan, hasil pengelompokan; misalnya jenis kelamin, hasil jawaban responden terhadap suatu quesioner; misalnya tingkat kepuasan.

\section{POPULASI}

Populasi adalah koleksi lengkap semua elemen yang akan diselidiki. Suatu koleksi dikatakan lengkap jika ia memuat semua subjek yang akan diselidiki.

\section{SAMPEL}

Sampel adalah sebagian koleksi anggota yang dipilih dari populasi.

\section{KLASIFIKASI STATISTIK}

Statistik berdasarkan cara pengolahan datanya dibagi menjadi dua macam yaitu: statistik deskriptif dan statistik inferensial.

\section{* Statistik deskriptif}

Statistik deskriptif atau statistik deduktif adalah bagian dari statistik yang mempelajari cara pengumpulan dan penyajian data sehingga mudah dipahami. Statistik ini dalam penyajian datanya memiliki beberapa bentuk diantaranya dalam bentuk tabel, grafik, ataupun diagram. hal ini dilakukan agar dalam 
penyajian data bisa menggambarkan gambaran yang teratur, ringkas, dan juga jelas mengenai suatu keadaan atau peristiwa. statistik deskriptif hanya berhubungan dengan hal-hal yang menguraikan keterangan-keterangan mengenai suatu data atau keadaan atau fenomena. Cakupan ruang lingkup pembahasan statistik deskriptif sendiri meliputi:

$\checkmark \quad$ Penyajian data dalam bentuk tabel.

$\checkmark$ Penyajian data dalam bentuk grafis.

$\checkmark$ Ukuran nilai pusat dan letak, seperti: rerata, median, modus, varian dll.

$\checkmark \quad$ Ukuran dispersi atau simpangan, seperti: jangkauan atu rentang dll.

$\checkmark$ Model distribusi data, kemencengan dan keruncingan kurva distribusi.

$\checkmark$ Angka indeks.

$\checkmark \quad$ Time series/deret waktu atau data berkala.

Dalam sumber lain statistik deskriptif terdiri atas :

- Distribusi frekuensi yaitu penyusunan data dari nilai terkecil sampai nilai terbesar yang kemudian disajikan dalam bentuk tabel atau diagram.

- Ukuran pemusatan yang terdiri atas rata-rata hitung, rata-rata letak, rata-rata harmonis, dan rata-rata geometris, serta median dan modus.

- Ukuran penyebaran terdiri atas rentangan (rank), simpangan, rata-rata, varians, dan simpangan baku. (subana, 2000)

Contoh-contoh pernyataan yang termasuk dalam cakupan statistik deskriptif diantaranya adalah:

- $\quad$ Sekurang-kurangnya $10 \%$ dari semua kebakaran disebuah kota tertentu yang dilaporkan tahun lalu diakibatkan oleh tindakan-tindakan sengaja yang tidak bertanggung jawab.

- Sebanyak 50\% diantara semua pasien yang menerima suntikan obat tertentu, ternyata kemudian menderita efek samping obat tersebut.

\section{* Statistik Inferensial}

Statistik inferensial atau statistik induktif adalah bagian dari statistik yang mempelajari mengenai penafsiran dan penarikan kesimpulan yang berlaku secara umum dari data yang telah tersedia. (hasan, 2003)

Statistik inferensial berhubungan dengan pendugaan populasi dan pengujian hipotesis dari suatu data atau keadaan atau fenomena. Dengan kata lain statistik inferensi berfungsi meramalkan dan mengontrol keadaan atau kejadian.

Berdasarkan ruang lingkup pembahasannya cakupan statistik inferensial meliputi :

$\checkmark$ Probalitas atau teori kemungkinan 
$\checkmark$ Distribusi teoritas

$\checkmark$ Sampling dan distribusi sampling

$\checkmark \quad$ Pendugaan populasi atau teori populasi

$\checkmark$ Uji hipotesis

$\checkmark$ Analisis korelasi dan uji signifikansi,dan

$\checkmark$ Analisis regresi untuk peramalan

Sedangkan hal-hal yang berhubungan dengan statistik inferensial adalah:

- Melakukan penafsiran tentang karakteristik populasi dengan menggunakan data yang diperoleh dari sampel.

- Membuat prediksi atau ramalan tentang masalah untuk masa yang akan datang.

- Menentukan ada tidaknya hubungan antar karakteristik.

- Menguji hipotesis.

- Membuat kesimpulan secara umum mengenai populasi.

\section{FUNGSI STATISTIK}

Menurut Budiyuwono (1987), fungsi-fungsi statistik diantaranya yaitu:

$>$ Statistik menggambarkan data dalam bentuk tertentu.

$>$ Statistik dapat menyederhanakan data yang kompleks menjadi data yang mudah dimengerti.

$>$ Statistik merupakan teknik untuk membuat perbandingan.

$>$ Statistik dapat memperluas pengalaman individual.

$>$ Statistik dapat mengukur besaran dari suatu gejala.

$>$ Statistik dapat menentukan hubungan sebab akibat.

\section{KEGUNAAN STATISTIK}

> Membantu peneliti dalam menggunakan sampel sehingga peneliti dapat bekerja efisien dengan hasil yang sesuai dengan objek yang ingin diteliti.

$>$ Membantu peneliti untuk membaca data yang telah terkumpul sehingga peneliti dapat mengambil keputusan yang tepat.

$>$ Membantu peneliti untuk melihat ada tidaknya perbedaan antara kelompok yang satu dengan kelompok yang lainnya atas objek yang diteliti.

$>$ Membantu peneliti untuk melihat ada tidaknya hubungan antara variabel yang satu dengan variabel yang lainnya.

$>$ Membantu peneliti dalam melakukan prediksi untuk waktu yang akan datang.

$>$ Membantu peneliti untuk melakukan interpretasi atas data yang terkumpul. 


\section{CIRI-CIRI STATISTIK}

Ciri-ciri atau karakteristik statistik menurut Sutrisno Hadi (1978) adalah sebagai berikut :

Statistik bekerja dengan angka.

$>$ Angka-angka dalam statistik memiliki dua arti yaitu angka statistik sebagai jumlah atau frekuensi dan angka statistik sebagai nilai atau harga.

$>$ Statistik bersifat objektif.

$>$ Artinya, angka statistik dapat digunakan sebagai alat pengungkap kenyataan dan kebenaran berbicara apa adanya.

$>$ Statistik bersifat universal.

> Statistik tidak hanya digunakan dalam satu disiplin ilmu saja, tetapi dapat digunakan secara universal dalam berbagai disiplin ilmu.

\section{CONTOH TABEL}

Tahun 2020

Jumlah Murid Sekolah Menurut Tingkat Sekolah dan Jenis Kelaminnya

\begin{tabular}{|l|l|l|l|l|}
\hline Jenis Kelamin & SD & SLTP & SLTA & Jumlah \\
\hline Laki-Laki & 4.758 & 2.795 & 1.459 & 9.012 \\
\hline Perempuan & 4.032 & 2.116 & 1.256 & 7.404 \\
\hline Jumlah & 8.790 & 4.911 & 2.715 & 16.416 \\
\hline
\end{tabular}

\section{KESIMPULAN}

Statistik adalah ilmu pengetahuan yang berhubungan dengan cara-cara pengumpulan data, pengolahan data, penganalisan data, penarikan kesimpulan, pembuatan keputusan yang cukup beralasan berdasarkan fakta yang ada. Sedangkan klasifikasi statistik berdasarkan metode pengolahannya ada dua macam yaitu statistik deskriptif dan statistik inferensial.

Data adalah hasil observasi atau pengamatan yang telah dikumpulan. Data dapat berupa hasil pengukuran; misalnya data tinggi dan berat badan, hasil pengelompokan; misalnya jenis kelamin, hasil jawaban responden terhadap suatu quesioner; misalnya tingkat kepuasan.

Populasi adalah koleksi lengkap semua elemen yang akan diselidiki. Suatu koleksi dikatakan lengkap jika ia memuat semua subjek yang akan diselidiki. Sampel adalah sebagian koleksi anggota yang dipilih dari populasi. 
Statistik deskriptif atau statistik deduktif adalah bagian dari statistik yang mempelajari cara pengumpulan dan penyajian data sehingga mudah dipahami, sedangkan Statistik inferensial atau statistik induktif adalah bagian dari statistik yang mempelajari mengenai penafsiran dan penarikan kesimpulan yang berlaku secara umum dari data yang telah tersedia.

Dan untuk fungsi statistik, kegunaan statistik, dan ciri-ciri statistik sendiri yaitu :

1. Statistik menggambarkan data dalam bentuk tertentu.

2. Statistik dapat menyederhanakan data yang kompleks menjadi data yang mudah dimengerti dll.

3. Kegunaan statistik adalah membantu peneliti dalam menggunakan sampel sehingga peneliti dapat bekerja efisien dengan hasil yang sesuai dengan objek yang ingin diteliti.

4. Membantu peneliti untuk membaca data yang telah terkumpul sehingga peneliti dapat mengambil keputusan yang tepat.

5. Sedangkan ciri-cirinya diantaranya Statistik bekerja dengan angka, Statistik bersifat objektif, dan Statistik bersifat universal.

\section{DAFTAR PUSTAKA}

1. Arsyam, M. (2020). MANAJEMEN PENDIDIKAN ISLAM.

2. Drs.Subana. (2000). STATISTIK PENDIDIKAN. BANDUNG: CV PUSTAKA SETIA.

3. Herianto, H. (2020). Teknik Menulis Artikel Konseptual.

4. Hasan, I. i. (2003). pokok-pokok materi statistik 1. jakarta: bumi aksara.

5. Herianto, H. (2020). Telaah Kurikulum 2013: Hasil Revisi Tahun 2018.

6. Jusmiana, A., \& Herianto, H. (2020). Suplemen Materi Statistik Terapan dalam Ilmu Kesehatan.

7. Sapada, A. O., \& Arsyam, M. (2020) Ilmu Pengetahuan dan Teknologi Menurut Pandangan Islam.

8. Sudijono, Anas. 2012. Pengantar Statistik Pendidikan. 